\title{
Assessment of Financial Sustainability of Local Budgets in the Budget Management System Using Kohonen Maps
}

\author{
Liubov Lysiak ${ }^{1, *}$, Svitlana Kachula², Anna Kushnir', Viktoriia Datsenko ${ }^{3}$, Tetiana Tereshchenko ${ }^{1}$ \\ ${ }^{1}$ Department of State, Local and Corporate Finance, University of Customs and Finance, 2/4 Volodymyra Vernadskoho Str., 49000, \\ Ukraine, Dnipro, Ukraine \\ ${ }^{2}$ Department of Finance, Banking and Insurance, Dnipro State Agrarian and Economic University, Serhiia Yefremova str., 25, 49000, \\ Ukraine, Dnipro, Ukraine \\ ${ }^{3}$ Department of Marketing, University of Customs and Finance, 2/4 Volodymyra Vernadskoho Str., 49000, Ukraine, Dnipro, Ukraine
}

Received September 26, 2021; Revised November 9, 2021; Accepted November 29, 2021

\section{Cite This Paper in the following Citation Styles}

(a): [1] Liubov Lysiak, Svitlana Kachula, Anna Kushnir, Viktoriia Datsenko, Tetiana Tereshchenko , "Assessment of Financial Sustainability of Local Budgets in the Budget Management System Using Kohonen Maps, "Universal Journal of Accounting and Finance, Vol. 9, No. 6, pp. 1558-1570, 2021. DOI: 10.13189/ujaf.2021.090633.

(b): Liubov Lysiak, Svitlana Kachula, Anna Kushnir, Viktoriia Datsenko, Tetiana Tereshchenko (2021). Assessment of Financial Sustainability of Local Budgets in the Budget Management System Using Kohonen Maps. Universal Journal of Accounting and Finance, 9(6), 1558-1570. DOI: 10.13189/ujaf.2021.090633.

Copyright $\odot 2021$ by authors, all rights reserved. Authors agree that this article remains permanently open access under the terms of the Creative Commons Attribution License 4.0 International License

\begin{abstract}
Systematic assessment of the financial stability of local budgets is important for timely detection of budget imbalances and identification of their causes, thus helping to make informed management decisions of current and strategic nature on the development of territories, quality local public services and improving welfare. The article proposes the use of Kohonen maps to determine the financial stability of local budgets. The main advantages of the practical use of Kohonen maps for this purpose compared to such common assessment methods as integrated and matrix are the simplification of the process of assessing the financial stability of local budgets and at the same time visualization of the results for public presentation. On Ukraine's example local budgets were grouped according to the parameters of their financial stability with the construction of Kohonen maps based on the SOM-Ward algorithm. It allowed determining the financial condition of local budgets of Ukraine during 2017-2020 and accordingly the type of their financial stability. Taking into account changes in the financial stability of local budgets over time is important when adjusting fiscal policy. The idea is that simplifying the process of assessing the financial stability of local budgets is an important condition for its active practical application and at the same time will allow visualizing information for
\end{abstract}

the public about local budgets which will promote transparency in budget management and increase trust in the formation of priorities of fiscal policy at the local level.

Keywords Ukraine, Local Budget, Budget System, Financial Stability, Budget Management, Kohonen's Self-Organization Map

JEL Classification: H70, H72, H74

Formulas: 0; fig.: 4; tab.: 3; ref.: 36

\section{Introduction}

Local budgets are a tool for implementing the policy of local governments on the development of a particular area, the implementation of local authorities of the most important tasks at the local level and obtaining the planned results. In the conditions of decentralization of power, the role of local budgets in stimulating the socio-economic development of territories, financing public needs and services of proper quality and improving the welfare of the population is significantly increasing. 
The general trend of development of countries with transformational economies in recent years is the intensification of practical implementation of budget decentralization reform which helped increase the role of local governments in addressing regional issues and strengthen their responsibility for financial stability of local budgets as a result of decisions.

In recent years the problems of financial support for the development of territories have worsened due to the rapid growth of current expenditures of local budgets. At the same time a significant decline in business activity of businesses especially small businesses and households rising unemployment led to a decrease in revenues to state and local budgets, to imbalances compared to the costs and needs of debt financing. In the context of global and local challenges significant rapid changes and in the course of the coronavirus pandemic, quarantine restrictions and threats of new waves, and the rapid growth of related budget expenditures and the need for debt financing, the problem of systematic timely assessment of financial stability of local budgets budget management is of particular importance.

Today the problems of financial support for territorial development remain acute and the mismatch between the financial capabilities and obligations of local governments in a certain period of time due to the influence of exogenous and endogenous factors can significantly disrupt the financial stability of local budgets. This can have significant negative consequences for territories and communities so a timely assessment of the financial sustainability of local budgets is currently relevant.

Given that the economic crisis has led to a significant decline in public confidence in the effectiveness of public financial management [10]. The assessment of the financial condition of local budgets should be made public in a timely manner.

In the process of making decisions on budget management, in order to improve the filling of the revenue side and optimize the expenditure part of the budget as well as meet public needs, local government should be flexible to changes in economic, budgetary and social spheres, be aware of the financial condition of the budget using budget planning and forecasting as well as apply the principles and tools of budget management etc.

\section{Literature Review}

Under the general approach budget sustainability is characterized by the ability of public authorities and local governments to timely and fully finance budget expenditures and maintains the share of budget deficit and public debt in gross domestic product at an economically reasonable level [7].

Currently the problems of deteriorating financial stability of local budgets are typical for many countries.
At the same time for small economies with high debt and greater vulnerability to climate change fiscal sustainability remains a priority challenge that requires an adequate fiscal policy response [6].

Financial stability depends on the vulnerability and flexibility of local budgets which are important components of their financial condition and are studied using various methods of analysis by many scholars: Zafra-Gómez, et al. (2009), Cabaleiro, et al. (2013), Padovani, et al. (2021) and other.

Cabaleiro R, Buch E, Vaamonde A. (2013) combining multidimensional statistical methods of principal component analysis and discriminant analysis offer a cumulative indicator to assess the financial condition of municipalities covering the dimension of resilience, flexibility and vulnerability and applying it to Spain. It is important that the method proposed by the researchers overcome the problem of weighing variables, optimizing the measurement of variability of all indicators that are included in the financial condition.

Padovani, et al. (2021) considers the financial vulnerability of municipalities and its analysis in the context of crises caused by pandemics in particular COVID-19. Thus, scholars consider the financial vulnerability of municipalities through the prism of three dimensions: the vulnerability associated with the external institutional framework of the municipal administrative structure and fiscal rules; vulnerability related to internal financial problems (described by generally accepted financial indicators); and vulnerabilities related to the municipality's ability to withstand the crisis. The vulnerability analysis is proposed to be conducted according to the following 4 groups of indicators: general administrative structure and fiscal rules, structure of municipal revenues, structure of municipal expenditures and vulnerability forecast. For each group, the types of sources of vulnerability and the sources of vulnerability are analyzed (lack of predictability and lack of ability to overcome). The results of a study on the example of Portugal and Italy showed significant vulnerability of municipalities to global pandemic crises.

Caldas, et al. (2018) examines Portuguese municipalities using the Council Sustainability Index (CSI) which combines four fundamental dimensions (governance, local government efficiency, socio-economic development and financial sustainability) and includes 25 specific criteria (each criterion is given appropriate weighting factor). In the study scientists use a multi-criteria decision analysis methodology (MCDA) and an additive evaluation model. This technique allows assessing the results of local government together with the analysis of financial stability and management assessment and identifying the main factors that explain the results. The problem of conducting such a study can be determined by its complexity and complexity.

Aleksandrova-Zlatanska (2019) established the 
relationship between socio-economic, demographic and financial factors and the fiscal position of municipalities, assessed the factors of fiscal stability of rural municipalities in Bulgaria using correlation and regression analysis. A model for assessing the propensity of rural municipalities to comply with the financial discipline of indices: one of which (K1) assesses the economic, social and administrative potential of the municipality and the other (K2) measures the propensity of the municipality and its leadership to violate fiscal discipline.

Santis (2020) analyzed the impact of demographic and economic factors on the financial stability of Italian municipalities based on the regression model and a number of indicators: population size and density, dependency ratio (working age population), population immigration, the ratio of current income to capital income, ratio current expenditures to capital expenditures, financial autonomy, current balance, level of indebtedness and level of investment.

In a number of other studies, the assessment of the financial stability of the budget system and in particular local finances is also based on the analysis of the system of indicators using integrated coefficients and determining the integrated indicator $[16,30]$ or building matrices $[8$, 28].

A review of the literature shows that the methods used by the above authors are effective in assessing the financial stability of the budget but require processing a large amount of information, time-consuming calculations which significantly complicates the process of evaluating a significant number of budgets simultaneously. In addition, the use of the integrated method is accompanied by a number of disadvantages, including a rigid set of weights in the models; high complexity of analytical work; complicated assessment of future development of the object; thresholds between rating levels are averaged and subjective as Mints (2018) points out. The problem of using an integrated method of assessing financial stability is characterized by considerable complexity (especially with a large data set) and high subjectivity at each stage. Also, if there is a significant discrepancy between the data values (for example, revenues and the budget coverage ratio) there will be a need to normalize the data (bringing all indicators to a value from 0 to 1 ) which complicates the evaluation process. The matrix method does not require normalization of data but does not take into account the priority of a particular indicator, and it is time consuming for a significant number of studied objects.

In modern conditions, the importance of systematic assessment of financial stability of local budgets is relevant for sound management decisions and requires the use of methods which are not cumbersome and allow to quickly process large amounts of information, quality analysis, minimization of subjective factors, accuracy, ability to visualize results and convenience in the process of practical application and at the same time demonstrated the dynamics of changes in the financial condition of local budgets, helped to identify weaknesses in the budget system which corresponds to the principle of transparency of the budget process and openness and efficiency of local authorities.

\section{Aims}

The purpose of the article is to assess the financial stability of local budgets using Kohonen`s self-organizing maps and determine the type of their financial stability on the example of Ukraine.

\section{Methodology and Methods}

The methodology for assessing the financial condition of local budgets in most studies is based on analyzing a particular list of financial indicators/ratios. Such calculations largely depend on the completeness of the input information contained in the financial statements and are characterized by large data sets and subjectivity of calculations. In general, we should agree with researchers who argue that conventional statistical methods, including clustering and forecasting methods, are not suitable for working with big data, reducing the size of a data set, or visualizing data that requires other approaches, in particular, neural networks $[9,11,12]$.

Assessing the financial stability of local budgets in Ukraine is a complex process (given its administrative-territorial structure and construction of the budget system), as it is based on determining a significant number of indicators and bringing their values to compare budgets requires additional calculations. That is why this work is done to assess the financial stability of local budgets as a complex system the method of neural networks - Kohonen's self-organizing maps (Self-Organizing Maps - SOM) was used. The choice of Kohonen's algorithm for clustering is due to the need to simplify the process of assessing the financial stability of budgets for more active use in management practice and reduce its subjectivity. SOM is a neural network of direct representation which uses an uncontrolled learning algorithm and through the process of self-organization configures the source blocks in the topological representation of the source data $[14,15]$.

This approach allows to group local budgets by their financial stability on the basis of a significant number of financial indicators and at the same time provides visualization of results. Analysis of Kohonen maps over time allows to clearly tracing changes in a large number of indicators that characterize the selected local budget. Due to these properties the SOM method is most often proposed in the management of complex financial systems [9]; Sarlin \& Peltonen (2011); Zarucjka (2012); Sarlin P. and Peltonen T. (2013); Joseph, \& Indratmo (2013) 
self-organizing maps are used in their work to display the state of financial stability and visualize the sources of systemic risks as well as to predict systemic financial crises. The effectiveness of this technique for the study of complex financial systems has been proven in many scientific papers when assessing financial condition and financial stability [17, 24, 27].

In this paper the clustering of local budgets in accordance with their sustainability indicators was carried out using an advanced algorithm SOM - SOM-Ward in software "Viscovery SOMine".

The SOM-Ward clustering approach is a two-tier clustering approach that uses the Ward clustering algorithm to determine SOM and clustering results. Mangiameli, Chen and West (1996) compared the efficiency of SOM and the hierarchical clustering method based on 252 data sets with different levels of imperfection which showed that the SOM method is superior to the hierarchical clustering method.

In the SOM-Ward clustering approach the process begins with accepting each node as a separate cluster. Clusters with a minimum Euclidean distance are combined in pairs until there is one cluster left on the map. When determining the distance both the Ward distance and the topological properties of the SOM are taken into account. In other words, the distance between two non-associated clusters is considered infinite and only related clusters are combined [33].

The main function of SOM is to display multidimensional data from network inputs on a two-dimensional map preserving the relationship between the data [13]. The location of points on the map reflects their relative similarity in multidimensional space i.e. the more the two data sets are similar to each other, the closer they will be on the resulting two-dimensional map.

SOM works according to a certain algorithm. Initially, random scales are assigned to spatially organized nodes. Next, a random sample of data is selected and the node that best matches the random sample at the adjacent distance is selected. Then the weight of the nodes adjacent to the winning node becomes more similar to the weights of the random sample taking into account their distance to the random sample. The SOM algorithm starts with a high learning speed and adjacent distance and then these parameters decrease slightly in subsequent iterations [12].

The use of Kohonen maps to analyze the financial condition of local budgets allows to clearly tracking changes in local budgets over time. Possibilities of visualization of placement of local parameters close in value according to their characteristics (indicators) in the color image next to each other in the center of the map. And the more different the indicators of certain local budgets, the further they will move away from the center to the borders of the map.

\section{Results}

Budget management is studied in the framework of budget management which is considered as "a system that covers the interaction of bodies for the preparation, review, approval and implementation of state and local budgets through a set of related functions, principles, methods, techniques, procedures and other budgetary tools aimed at the development and implementation of management decisions and used to ensure the efficient and targeted use of financial resources" [21]. Implementation of effective budget management at the local level involves among other important tasks in compliance with the requirement of transparency of the budget process, public participation in local development decisions - achieving sustainability of local budgets as an important comprehensive characteristic of their financial condition. Financial analysis of the budget plays an important role in improving the management of local budget funds [18].

It is an important condition for the functioning and improvement of the local budget management system is a full and comprehensive analysis of their financial condition which in turn should be based on financial stability indicators as financial stability analysis allows assessing in detail the local budget, its balance, independence, capacity and effectiveness. It can be argued that the financial stability of the local budget on the one hand is a tool of budget management, and on the other hand serves as an indicator of the effectiveness of budget management.

\subsection{Construction of Kohonen Maps on the Basis of Parameters of Financial Stability of Local Budgets on Ukraine`s Example}

The SOM mathematical apparatus allows you to process multidimensional arrays and display the result on a two-dimensional plane. Kohonen's self-organizing map is compared to a geographical map. In our case, each item on the map corresponds to a specific local budget. The position of the local funding is determined based on the values of specific indicators. The closeness of the location of budgets on the Kohonen map indicates the proximity of the characteristics of their financial condition and financial stability. Using the values of the system of indicators allows assessing various aspects of the financial situation of local budgets and identifying problem areas that require increased attention and the necessary management decisions/measures.

According to the Budget Code of Ukraine all local budgets are independent which is ensured by securing the relevant sources of budget revenues, the right of local authorities to determine the use of budget funds in accordance with Ukrainian legislation, the right of relevant local councils to consider and approve relevant local budgets. The basis of financial independence of local 
government budgets is the income of local budgets. Given the construction of the budget system and the administrative-territorial division in Ukraine, it should be noted that the assessment of the financial condition of local budgets includes a significant number of objects (budgets). The budget system of Ukraine according to the Ministry of Finance in 2020 included 8838 local budgets regional budgets and the budget of the Autonomous Republic of Crimea (ARC) (25 budgets); budgets of cities of republican/regional significance (145 budgets); district budgets (488 budgets); budgets of united territorial communities (872 budgets); district budgets in cities of regional significance (40 budgets); budgets of cities of district significance (16 budgets); budgets of urban-type settlements (507 budgets); village budgets (6597 budgets) [22].

For this study local budgets were selected in the regional context ( 25 objects - regional budgets) and a set of indicators that comprehensively characterize the local budget and its financial stability. Indicators for assessing the financial stability of local budgets and determining their priority for clustering are chosen using algorithms of Kohonen neural networks due to the construction of the budget and tax system of Ukraine, the availability of publicly available information $[22,31]$ as well as scientific approaches to assessing the financial sustainability of budgets in Ukraine in previous studies [3, $16,19]$.

Also, what is added to the list of indicators is a financial indicator such as the level of redistribution of gross regional product (GRP) through the local budget (the ratio of total local budget revenues to GRP) which allows outlining the level of centralization of the region's financial system. It is considered that the use of this indicator expedient as it shows the connection of the local budget with the economy of the region which is relevant in the conditions of uneven socio-economic development of the regions.

Table 1 summarizes the indicators of financial stability of local budgets, their characteristics and priorities.

Table 1. Characteristics of indicators of financial stability of local budgets

\begin{tabular}{|c|c|}
\hline Indicator & Characteristic of the indicator / priority \\
\hline 1. Budget coverage ratio & $\begin{array}{l}\text { ensuring the implementation of the expenditure part at the expense of } \\
\text { budget revenues, i.e., its balance / } 1.5\end{array}$ \\
\hline 2. Coefficient of budget independence & $\begin{array}{l}\text { dependence of the revenue side of local budgets on the state budget / } \\
1.5\end{array}$ \\
\hline Budget performance indicator & budget revenues per person / 1.2 \\
\hline Indicator of budget economic security of the population & budget expenditures per person / 1.2 \\
\hline $\begin{array}{l}\text { 5. An indicator of the stability of the revenue side of the } \\
\text { budget }\end{array}$ & the ratio of tax revenues to transfers from the state budget / 1.2 \\
\hline $\begin{array}{l}\text { 6. Expenditure coverage ratio by intergovernmental transfers } \\
\text { and debt burden on revenues }\end{array}$ & $\begin{array}{l}\text { shows the dependence of budget expenditures on state budget funds / } \\
1.0\end{array}$ \\
\hline The coefficient of stability of the income base & $\begin{array}{l}\text { determines the security of the budget at the expense of its tax and } \\
\text { non-tax revenues / } 1.0\end{array}$ \\
\hline The level of GRP redistribution through the local budget & $\begin{array}{l}\text { characterizes the accumulation of revenues from the economy and } \\
\text { shows the level of centralization of the financial system of the } \\
\text { administrative-territorial unit / } 1.0\end{array}$ \\
\hline 9. Debt burden on budget revenues & $\begin{array}{l}\text { shows the ratio of debt service expenditures to the revenue side of the } \\
\text { budget / } 0.6\end{array}$ \\
\hline
\end{tabular}

Source: compiled by the authors 
In the process of constructing SOM based on selected indicators, the following main parameters were set. The map was trained with 1000 nodes and an automatic ratio (38:27); the "Normal" training schedule with a voltage of 0.5 was chosen; the SOM-Ward-Clusters method with the definition of 5 clusters was chosen for clustering. The functionality of the program allows data processing without their normalization.

Figures 1-4 show the results of clustering of regional budgets of Ukraine by their financial stability in 2017-2020.

On the received maps the numbers from 1 to 25 in alphabetical order indicate the location of local budgets by region in accordance with their indicators of financial stability. That is in figures $1-4$ the following symbols are used: local budgets of Vinnytsia region is indicated on the map by number (1), local budgets of Volyn region - by number (2), Dnipropetrovsk region - (3), Donetsk region (4), Zhytomyr region - (5), Zakarpattia region - (6), Zaporizhzhia region - (7), Ivano-Frankivsk region - (8), Kyiv region - (9), Kirovohrad region - (10), Luhansk region - (11), Lviv region - (12), Mykolaiv region - (13), Odessa region - (14), Poltava region - (15), Rivne region (16), Sumy region - (17), Ternopil region - (18), Kharkiv region - (19) ), Kherson region - (20), Khmelnytskyi region - (21), Cherkasy region - (22), Chernivtsi region (23), Chernihiv region - (24), Kyiv (city) - (25). In turn the designation of clusters using the symbols C1-C5 as well as color separation is due to software features. Since the "Viscovery SOMine" program takes into account the number of elements when providing the cluster serial number and color scheme observe differences in the numbering and color of the clusters in different years of the study period. Thus, when reading the obtained Kohonen maps it is necessary to pay attention to where the cluster is located on the map and the elements inside the cluster. Thus, the best indicators of financial stability will have elements of the cluster located in the lower left corner and the worst - in the upper right and lower corners.

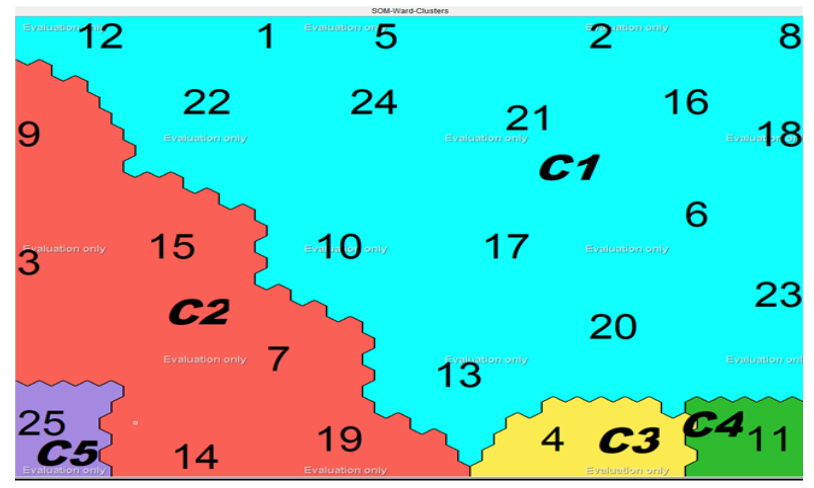

Source: built by the authors

Figure 1. Clustering of regional budgets by their financial stability in 2017
In 2017, according to the input data, the following clusters were formed:

- Cluster $\mathrm{C} 1$ includes the following regions: Vinnytsia, Volyn, Zhytomyr, Zakarpattia, Ivano-Frankivsk, Kirovohrad, Lviv, Mykolaiv, Rivne, Sumy, Ternopil, Kherson, Khmelnytsky, Cherkasy, Chernivtsi, Chernihiv regions. The closest to the $\mathrm{C} 2$ cluster are: Kirovohrad, Lviv, Mykolaiv, Sumy, Chernihiv and Cherkasy regions which indicates their better financial stability compared to other regions of the cluster;

- Cluster $\mathrm{C} 2$ is characterized by high indicators of financial stability of budgets and includes 6 regions: Dnipropetrovsk, Zaporizhia, Kyiv, Odessa, Poltava and Kharkiv. The closest to the C5 cluster are Dnipropetrovsk and Odessa regions.

- Cluster C3 and C4 include Donetsk and Luhansk regions respectively. These clusters are located in the lower right corner of the map and are characterized by unsatisfactory indicators of financial stability of budgets;

- Cluster C5 has the best results in terms of parameters and includes one element - Kyiv.

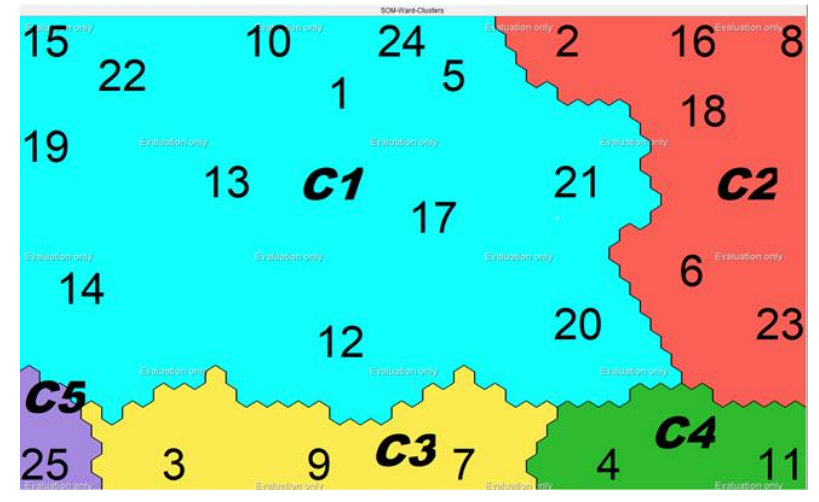

Source: built by the authors

Figure 2. Clustering of regional budgets by their financial stability in 2018

When constructing Kohonen maps based on financial stability indicators in 2018, the following distribution of regional budgets was obtained:

- Cluster C1 includes the following oblasts: Vinnytsia, Zhytomyr, Kirovohrad, Lviv, Mykolaiv, Odesa, Poltava, Sumy, Kharkiv, Kherson, Khmelnytsky, Cherkasy and Chernihiv. The closest to the C5 cluster are Odessa and Kharkiv regions. Zhytomyr, Kherson, Khmelnytsky and Chernihiv regions have the worst indicators according to the location on the map;

- Cluster C2 is located in the upper right corner and includes the following regions: Volyn, Zakarpattia, Ivano-Frankivsk, Rivne, Ternopil and Chernivtsi. In 2017, these regions were also located in this part of the map. And although this cluster is characterized 
by a high coefficient of budget coverage in 2017 there is a high dependence on state budget funds;

- Cluster C3 is located next to cluster C5 and includes Dnipropetrovsk (closest location to cluster C5), Kyiv and Zaporizhia (located closer to the lower right edge of the map) regions;

- Cluster C4 includes Donetsk and Luhansk regions observe the convergence of these elements in accordance with the indicators of financial stability, compared to 2017;

- Cluster C5 includes the city of Kyiv.

Figure 3 shows the results of clustering of regional budgets of Ukraine by their financial stability in 2019 .

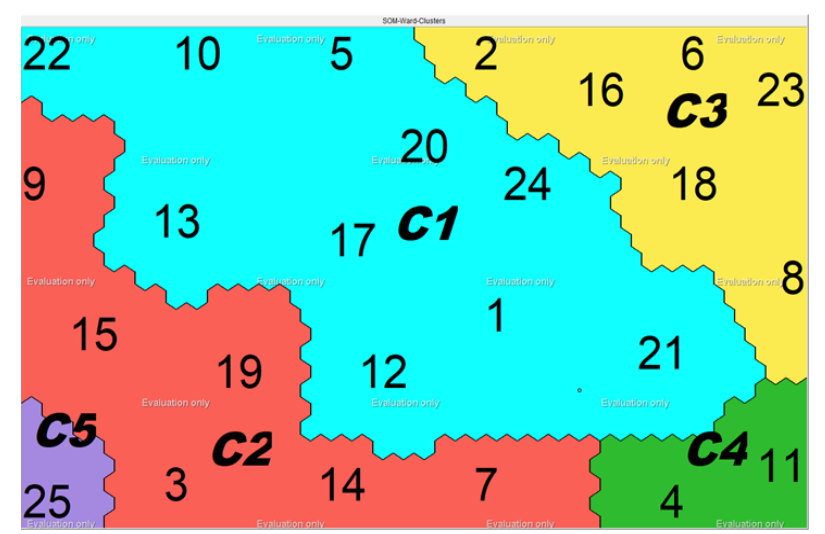

Source: built by the authors

Figure 3. Clustering of regional budgets of Ukraine by their financial stability in 2019

Thus, the following distribution of budgets of the regions of Ukraine by their financial stability in 2019 was obtained:

- Cluster C1 includes the largest number of elements ( $40 \%$ of the total number of regions) and is located between clusters C2, C4 and C3. This cluster includes 10 regions: Vinnytsia, Zhytomyr, Kirovohrad, Lviv, Mykolaiv, Sumy, Kherson, Khmelnytsky, Cherkasy, Chernihiv. According to the visualization of the parameters of financial stability of local budgets, the best results in most indicators are typical for regional budgets which are closer to the C2 cluster (Lviv region, Kirovohrad region, Mykolaiv region and Cherkasy region). Regions located in the middle of cluster $\mathrm{C} 1$ and closer to clusters C4 and C5 have worse results in terms of financial stability;

- Cluster C2 includes 6 oblasts: Dnipropetrovsk, Zaporizhia, Kyiv, Odesa, Poltava, Kharkiv and is characterized by fairly high results in almost all selected indicators of financial stability. The closest to the C5 cluster are Dnipropetrovsk and Poltava regions. Indicators of financial stability of budgets in these regions are close to those of Kyiv. In turn Kharkiv, Odesa, Kyiv and Zaporizhia oblasts have slightly lower results in their cluster. Thus, these regions are located closer to the cluster $\mathrm{C} 1$ (Kharkiv, Odessa, Kyiv and Zaporizhia regions) and $\mathrm{C} 4$ (Zaporizhia region);

- Cluster C3 also includes 6 oblasts: Volyn, Zakarpattia, Rivne, Ternopil, Chernivtsi, Ivano-Frankivsk;

- Cluster C4 includes 2 regions: Donetsk and Luhansk;

The regions in cluster $\mathrm{C} 4$ (lower right corner) and $\mathrm{C} 3$ (upper right corner) have the worst results in almost all indicators of financial stability of budgets. These regions have significant budget deficits, dependence on central government funds, insufficient stability of the revenue base and low budget performance as well as the highest level of centralization of the financial system of the regions. Cluster $\mathrm{C} 4$ is characterized by a significant excess of expenditures over budget revenues, low performance and security of the population compared to the areas included in cluster C3. This situation is explained by the conduct of hostilities in parts of these areas. However, the elements of cluster C4 compared to cluster C3 have greater independence from the State budget, higher stability and stability of the revenue base.

- Cluster C5 includes only the city of Kyiv. Thus, this cluster is characterized by a budget surplus, high independence from transfers from the State Budget of Ukraine, high stability of the revenue base and stability of budget revenues as well as the highest indicators of budget efficiency and security. In addition, Kyiv has the lowest rate of centralization of the region's financial system.

Figure 4 shows the results of clustering of regional budgets of Ukraine by their financial stability in 2020 .

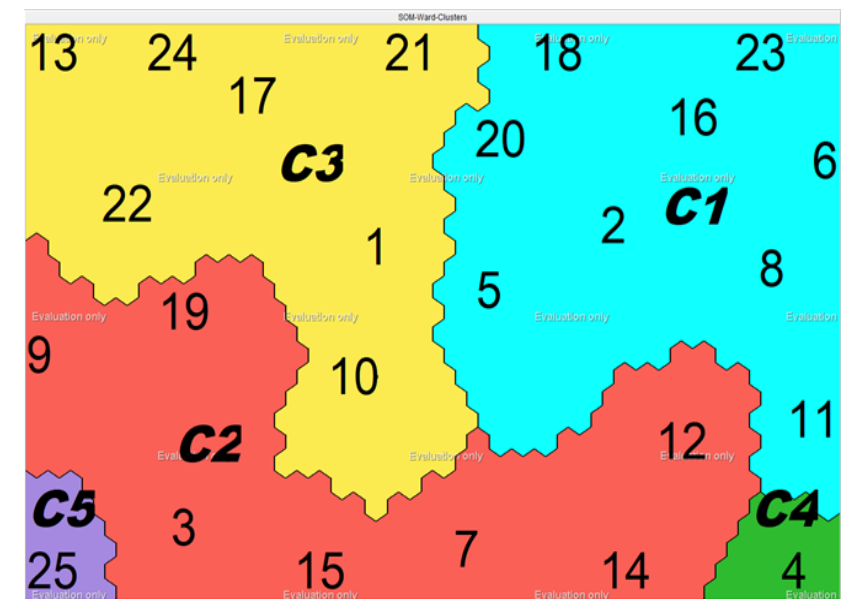

Source: built by the authors

Figure 4. Clustering of regional budgets of Ukraine by their financial stability in 2020

When constructing Kohonen maps based on indicators of financial stability in 2020, the following distribution of regional budgets was obtained: 
- Cluster C1 includes the largest number of elements (36\% of the total number of regions): Volyn, Zhytomyr, Zakarpattia, Ivano-Frankivsk, Luhansk, Rivne, Ternopil, Kherson and Chernivtsi regions. This cluster is located in the upper right corner and has the worst indicators of financial stability of budgets;

- Cluster C2 includes 7 oblasts: Dnipropetrovsk, Zaporizhia, Kyiv, Lviv, Odesa, Poltava, Kharkiv and is characterized by quite high results in most of the selected indicators of financial stability. The closest to the C5 cluster are Dnipropetrovsk, Kyiv and Poltava regions which indicates better indicators of their financial stability compared to other elements of the cluster. In turn Lviv and Odesa oblasts are significantly far from cluster C5 and close to clusters $\mathrm{C} 1$ and $\mathrm{C} 4$ i.e., they have the lowest indicators of financial stability in their cluster. Comparing with the results of clustering in 2019 can see that the Odessa region was also quite far from the city of Kyiv and the Lviv region belonged to the cluster located in the middle of the map;

- Cluster C3 includes 6 oblasts: Vinnytsia, Kirovohrad, Mykolaiv, Sumy, Khmelnytsky, Cherkasy and Chernihiv oblasts and occupies the upper left corner and the center of the formed map. The best parameters of financial stability are inherent in Kirovohrad and Cherkasy regions and the worst - in Khmelnytsky region;

- Cluster C4 includes the Donetsk region. This region is characterized by significant budget deficits, low budget efficiency and security, sufficient stability of the revenue base and high budget independence;

- Cluster C5 only includes the city of Kyiv and is characterized by the highest indicators of financial stability of local budgets.

It should be noted that the average values of such statistical indicators of the financial condition of the budget as revenues (tax revenues and intergovernmental transfers) differ significantly by clusters and do not correspond to the results of clustering based on indicators of financial stability. A striking example is the $\mathrm{C} 4$ cluster reflected in the maps for 2018-2019, the elements of which differ significantly in their statistics. For example, the revenues of the consolidated budget of the Donetsk region in 2019 amounted to UAH 26,500.8 million (indicators are close to the statistical indicators of the elements of the $\mathrm{C} 2$ cluster) while the Luhansk region UAH 9,116.7 million. However, in terms of relative indicators (indicators of financial stability) these elements are the closest. This is due to the fact that statistics (in absolute terms) do not allow assessing the real financial condition of budgets and its change over time. Thus, the positive dynamics of tax revenues of the budget does not indicate an improvement in its stability and independence if the increase in intergovernmental transfers will exceed the increase in tax revenues. Thus, this explains the importance of using relative indicators of the financial condition of the budget to compare local budgets.

\subsection{Determination of the Type of Financial Sustainability of Local Budgets on the Basis of Kohonen Maps}

An important step in the study of financial stability of local budgets is to determine the type of financial stability. To do this, it is necessary to consider the average values of the parameters of the obtained clusters and compare them with the normative values. The constructed maps clearly show the deterioration of the financial stability of regional budgets from the lower left to the upper right. Kohonen's self-organizing maps allow clustering budgets taking into account the proximity of parameters to each other. However, if all the selected elements have parameters that characterize the high stability of budgets then as a result, without comparison with the normative values, the results obtained will not outline the division of budgets by types of financial stability. Therefore, it is mandatory to use normative values when determining the financial stability of the local budget.

Table 2 presents data on the average values of the obtained clusters in 2017-2020. To facilitate the comparison of clusters for the selected period of time, a new numbering of clusters was performed based on the results of their financial stability where $\mathrm{A}$ is given to the cluster with the best average parameters and $\mathrm{E}$ - the worst. 
Table 2. Average values of parameters by clusters

\begin{tabular}{|c|c|c|c|c|c|c|c|c|c|c|}
\hline $\begin{array}{c}\text { Cluster } \\
\text { number } \\
\text { on the } \\
\text { map }\end{array}$ & $\begin{array}{c}\text { Cluster } \\
\text { number } \\
\text { according to } \\
\text { the results }\end{array}$ & $\begin{array}{l}\text { Budget } \\
\text { coverage } \\
\text { ratio }\end{array}$ & $\begin{array}{c}\text { Coefficient of } \\
\text { budget } \\
\text { independence }\end{array}$ & $\begin{array}{c}\text { Budget } \\
\text { performance } \\
\text { indicator, UAH }\end{array}$ & $\begin{array}{c}\text { Indicator of } \\
\text { budget security of } \\
\text { the population, } \\
\text { UAH }\end{array}$ & $\begin{array}{l}\text { Indicator of } \\
\text { stability of the } \\
\text { revenue part of } \\
\text { the budget }\end{array}$ & $\begin{array}{c}\text { Coefficient of } \\
\text { coverage of expenses } \\
\text { by intergovernmental } \\
\text { transfers }\end{array}$ & $\begin{array}{l}\text { Coefficient of } \\
\text { stability of the } \\
\text { income base }\end{array}$ & $\begin{array}{l}\text { The level of } \\
\text { redistribution of } \\
\text { GRP through the } \\
\text { local budget, } \%\end{array}$ & $\begin{array}{c}\text { Debt burden } \\
\text { on budget } \\
\text { revenues, } \%\end{array}$ \\
\hline & \multicolumn{10}{|c|}{2017} \\
\hline C 1 & $\mathrm{D}$ & 1,022 & 0,364 & 12382 & 12121 & 0,503 & 0,650 & 0,360 & 25,85 & 0,004 \\
\hline C 2 & $\mathrm{~B}$ & 1,010 & 0,508 & 13260 & 13113 & 0,922 & 0,497 & 0,503 & 16,18 & 0,013 \\
\hline C 3 & $\mathrm{C}$ & 1,027 & 0,463 & 6135 & 5971 & 0,759 & 0,552 & 0,461 & 15,52 & 0,262 \\
\hline $\mathrm{C} 4$ & $\mathrm{E}$ & 0,900 & 0,394 & 3690 & 4099 & 0,557 & 0,546 & 0,392 & 26,53 & 0,000 \\
\hline \multirow[t]{2}{*}{ C 5} & A & 0,985 & 0,718 & 16881 & 17139 & 2,189 & 0,278 & 0,708 & 6,97 & 0,031 \\
\hline & \multicolumn{10}{|c|}{2018} \\
\hline C 1 & $\mathrm{C}$ & 0,996 & 0,428 & 14221 & 14275 & 0,676 & 0,570 & 0,423 & 20,06 & 0,042 \\
\hline C 2 & $\mathrm{D}$ & 1,001 & 0,317 & 13605 & 13596 & 0,395 & 0,684 & 0,311 & 28,57 & 0,022 \\
\hline C 3 & $\mathrm{~B}$ & 0,959 & 0,528 & 15321 & 15977 & 1,010 & 0,453 & 0,524 & 14,84 & 0,058 \\
\hline $\mathrm{C} 4$ & $\mathrm{E}$ & 0,969 & 0,431 & 5317 & 5520 & 0,669 & 0,553 & 0,430 & 19,99 & 0,000 \\
\hline \multirow[t]{2}{*}{ C 5} & A & 0,983 & 0,731 & 19691 & 20029 & 2,370 & 0,265 & 0,721 & 6,86 & 0,689 \\
\hline & \multicolumn{10}{|c|}{2019} \\
\hline C 1 & $\mathrm{C}$ & 0,992 & 0,477 & 13767 & 13878 & 0,819 & 0,519 & 0,470 & 18,26 & 0,028 \\
\hline C 2 & B & 0,984 & 0,583 & 15032 & 15270 & 1,290 & 0,410 & 0,578 & 14,20 & 0,226 \\
\hline C 3 & $\mathrm{D}$ & 0,988 & 0,368 & 13284 & 13449 & 0,507 & 0,624 & 0,361 & 23,50 & 0,055 \\
\hline $\mathrm{C} 4$ & $\mathrm{E}$ & 0,967 & 0,488 & 5334 & 5514 & 0,872 & 0,494 & 0,487 & 17,77 & 0,016 \\
\hline \multirow[t]{2}{*}{ C 5} & A & 1,018 & 0,780 & 21324 & 20944 & 3,216 & 0,224 & 0,773 & 6,55 & 0,372 \\
\hline & \multicolumn{10}{|c|}{2020} \\
\hline $\mathrm{C} 1$ & $\mathrm{D}$ & 0,996 & 0,512 & 9861 & 9882 & 0,952 & 0,487 & 0,502 & 16,27 & 0,089 \\
\hline $\mathrm{C} 2$ & $\mathrm{~B}$ & 0,980 & 0,695 & 12797 & 13054 & 2,124 & 0,299 & 0,683 & 10,82 & 0,852 \\
\hline $\mathrm{C} 3$ & $\mathrm{C}$ & 1,002 & 0,620 & 11380 & 11353 & 1,510 & 0,381 & 0,616 & 12,82 & 0,037 \\
\hline $\mathrm{C} 4$ & $\mathrm{E}$ & 0,900 & 0,676 & 5447 & 6051 & 1,881 & 0,292 & 0,674 & 9,57 & 0,158 \\
\hline $\mathrm{C} 5$ & A & 1,003 & 0,852 & 19881 & 19821 & 5,365 & 0,148 & 0,844 & 5,38 & 0,506 \\
\hline \multicolumn{2}{|c|}{$\mathrm{N}$} & $\geq 1$ & $\geq 0,5$ & $\uparrow$ & $\uparrow$ & $\uparrow$ & $\leq 0,5$ & $\geq 0,5$ & $\downarrow$ & $\downarrow$ \\
\hline & $\mathrm{P}$ & 1,5 & 1,5 & 1,2 & 1,2 & 1,2 & 1 & 1 & 1 & 0,6 \\
\hline & \multicolumn{10}{|c|}{$P$ - priority of the indicator; $\mathrm{C} i-$ cluster number; $N$-normative values } \\
\hline
\end{tabular}

Source: built by the author 
According to the indicators of financial stability of local budgets the best results during the study period is cluster A (No.5) which is confirmed by the average values of indicators. In addition, an increase is observed in the values of financial stability parameters for 2017-2019, which indicates an improvement in the financial condition of the element of cluster A (Kyiv). The isolation of cluster $B$ is clearly traced by the results of its parameters, the elements of which are also characterized by a high value of almost all indicators of financial stability. During the selected period there was an increase in the independence of local budgets from the State Budget of Ukraine, budget efficiency and security, stability of budget revenues as well as reducing the debt burden. In 2018 and 2017 there is a deficit of budgets of cluster B. Given the data obtained the priority of parameters as well as the location of clusters on the constructed maps the worst in terms of financial stability is cluster No.4 (E). The ambiguity of the obtained results for other clusters made it difficult to determine the compliance of clusters with their results.

Based on the above study and compared with regulatory values, the types of financial stability of the budgets of the regions of Ukraine for 2017-2020 were identified (Table $3)$.

Table 3. Clustering of financial stability of budgets of regions of Ukraine for 2017-2020

\begin{tabular}{|c|c|c|c|c|}
\hline High stability & Normal stability & Moderate stability & Weak stability & Problem budget \\
\hline \multicolumn{5}{|c|}{ region } \\
\hline region & $\begin{array}{c}\text { Dnipropetrovsk region, } \\
\text { Zaporizhzhia region, } \\
\text { Kyiv region, } \\
\text { Odesa region, } \\
\text { Poltava region, } \\
\text { Kharkiv region }\end{array}$ & $\begin{array}{l}\text { Vinnytsia region, Volyn } \\
\text { region, Zhytomyr region, } \\
\text { Zakarpattia region, } \\
\text { Ivano-Frankivsk region, } \\
\text { Kirovohrad region, Lviv } \\
\text { region, Mykolaiv region, } \\
\text { Rivne region, Sumy region, } \\
\text { Ternopil region, Kherson } \\
\text { region, Khmelnytskyi region, } \\
\text { Cherkasy region, Chernivtsi } \\
\text { region, Chernihiv region, } \\
\text { Donetsk region } \\
\end{array}$ & & Luhansk region \\
\hline \multicolumn{5}{|c|}{2018} \\
\hline Kyiv & $\begin{array}{c}\text { Dnipropetrovsk region, } \\
\text { Zaporizhzhia region, } \\
\text { Kyiv region }\end{array}$ & $\begin{array}{l}\text { Vinnytsia region, Zhytomyr } \\
\text { region, Kirovohrad region, } \\
\text { Lviv region, Mykolaiv region, } \\
\text { Odesa region, Poltava region, } \\
\text { Sumy region, Kharkiv region, } \\
\text { Kherson region, Khmelnytskyi } \\
\text { region, Cherkasy region, } \\
\text { Chernihiv region }\end{array}$ & $\begin{array}{c}\text { Volyn region, } \\
\text { Zakarpattia region, } \\
\text { Rivne region, Ternopil } \\
\text { region, Chernivtsi } \\
\text { region, } \\
\text { Ivano-Frankivsk region }\end{array}$ & $\begin{array}{l}\text { Donetsk region, } \\
\text { Luhansk region }\end{array}$ \\
\hline \multicolumn{5}{|c|}{2019} \\
\hline Kyiv & $\begin{array}{l}\text { Dnipropetrovsk region, } \\
\text { Zaporizhzhia region, } \\
\text { Kyiv region, Odesa } \\
\text { region, Poltava region, } \\
\text { Kharkiv region }\end{array}$ & $\begin{array}{l}\text { Vinnytsia region, Zhytomyr } \\
\text { region, Kirovohrad region } \\
\text { Lviv region, Mykolaiv region, } \\
\text { Sumy region Kherson region, } \\
\text { Khmelnytskyi region, } \\
\text { Cherkasy region, Chernihiv } \\
\text { region }\end{array}$ & $\begin{array}{c}\text { Volyn region, } \\
\text { Zakarpattia region, } \\
\text { Rivne region, Ternopil } \\
\text { region, Chernivtsi } \\
\text { region, } \\
\text { Ivano-Frankivsk region }\end{array}$ & $\begin{array}{l}\text { Donetsk region, } \\
\text { Luhansk region }\end{array}$ \\
\hline \multicolumn{5}{|c|}{2020} \\
\hline Kyiv & $\begin{array}{l}\text { Dnipropetrovsk region, } \\
\text { Zaporizhzhia region, } \\
\text { Kyiv region, Lviv } \\
\text { region, Odesa region, } \\
\text { Poltava region, Kharkiv } \\
\text { region, Vinnytsia, } \\
\text { Kirovohrad region, } \\
\text { Mykolaiv region, Sumy } \\
\text { region, Khmelnytskyi } \\
\text { region, Cherkasy region, } \\
\text { Chernihiv region }\end{array}$ & $\begin{array}{l}\text { Volyn region, Zhytomyr } \\
\text { region, Zakarpattia region, } \\
\text { Ivano-Frankivsk region, } \\
\text { Luhansk region, Rivne region, } \\
\text { Ternopil region, Kherson } \\
\text { region, Chernivtsi region, } \\
\text { Donetsk region }\end{array}$ & & \\
\hline
\end{tabular}


The worst results for three years belonged to Luhansk region, the best - to Kyiv. In 2018 Odesa, Poltava and Kharkiv regions were included in the cluster which has moderate financial stability of the budget but their location on the formed Kohonen maps (they are close to the cluster with normal budget stability) and the values of financial stability allow concluding that these regions are on the border between normal and moderate resilience. A similar situation is typical for Volyn, Zakarpattia, Rivne, Ternopil, Chernivtsi and Ivano-Frankivsk regions which in 2018 are located closer to the cluster with weak and very weak financial stability. In 2017, clusters No.1 (Vinnytsia, Volyn, Zhytomyr, Zakarpattia, Ivano-Frankivsk, Kirovohrad, Lviv, Mykolaiv, Rivne, Sumy, Ternopil, Kherson, Khmelnytskyi, Cherkasy, Chernivtsi, Chernihiv regions) and No.3 (Donetsk region) are compared in terms of the average values of indicators with regulatory values are classified as a moderate type of financial stability. In general, the obtained data indicate the predominance of moderate and weak financial stability of the budgets of the regions of Ukraine in 2017-2019.

The results obtained on the indicators of financial stability of local budgets of Ukraine in 2020 indicate an improvement in the financial condition of regional budgets which occurred due to the deepening of decentralization processes and the expansion of sources of local budget revenues. Thus, in accordance with the normative values of most budgets normal (14 elements) and moderate (10 elements) financial stability were inherent. This requires appropriate adjustments to fiscal policy and the adoption of sound management decisions and measures. The most important condition for effective socio-economic development of the local budget is the formation and implementation of a strategy to ensure its financial stability which should be chosen according to the type of financial stability of the territory [2]. That is determining the type of financial stability of the local budget allows using the method of benchmarking, to identify similar problems in the budget process and mechanism inherent in the budgets of a certain type of stability, as well as to develop an effective financial strategy.

The use of Kohonen maps will simplify the process of assessing the financial sustainability of local budgets which will allow more active use of local governments and self-government in practice as it has advantages over other methods for use in analyzing the financial stability of local budgets. The advantages include: the ability to process a large array of data; speed and simplification of the evaluation process with the use of available software; visualization of results; reducing the subjectivity of the results; the ability to evaluate cluster elements due to their proximity to other clusters.

At the same time when assessing the financial stability of local budgets using Kohonen maps it is important to understand and take into account their shortcomings.
Among the disadvantages: the movement/migration of an element in clusters in time depends on the dynamics of the parameters of other elements; there is a need to compare with normative values (for example, two clusters can correspond to one type of financial stability); the high level of qualification (knowledge) of the researcher is important for adequate interpretation of the obtained results.

It is important that SOM should be used when the researcher understands the results and interprets them correctly. Subject matter expertise is important and should always play a key role in ensuring the effective application of SOM [9]. Thus, the interpretation of the obtained data and determining the type of financial stability of a cluster requires thorough knowledge on this topic which may require additional training.

Despite the shortcomings the use of Kohonen maps allows to improve and simplify the process of assessing the financial stability of local budgets for practical application taking into account certain conditions. Thus, the effectiveness of clustering depends on a reliable sample of data and prioritization of indicators as well as a high level of knowledge of the researcher in this topic. The issue of choosing indicators for assessing the financial stability of local budgets as well as reducing the level of subjectivity in determining their priority remains open.

The problem of using the results of financial stability as a tool for managing local budgets in Ukraine is the lack of legally established requirements for its conduct and at the same time the difficulty of assessing financial stability due to the large number of time-consuming calculations. At the same time timely systematic assessment of the use of financial stability indicators will improve the information support of local governments on the formation and use of budget resources, identify problems in the budget process at the local level and assess the effectiveness of local government decisions on socio-economic development. In modern conditions the completion of budget decentralization in Ukraine and strengthening the responsibility of local governments for social and economic development of the community requires quality budget management which is impossible without specialized tools and the use of appropriate software.

\section{Conclusions}

Local budgets in the budget system of each country reflect the state of the economy. Social sphere is characterized by a significant intertwining of divergent interests of participants in the budget process their stability determines the positive dynamics of socio-economic development of territories and the country. Timely assessment of the financial condition of local budgets is important for the implementation of an open, 
modern, innovative and accountable public local government, making sound management decisions and ensuring the transparency of the budget process.

The article assesses the financial stability of regional budgets of Ukraine using Kohonen maps on the basis of important indicators and visualization of the results and identifies the type of financial stability of 25 regional budgets of Ukraine. The closeness of the location of budgets on the Kohonen map indicates the closeness of the characteristics of their financial condition and financial stability. The formation of maps for the period 2017-2020 was carried out which allowed assessing the financial stability of regional budgets in the dynamics. The obtained results allowed dividing the budgets of the regions of Ukraine according to the type of their financial stability which will allow the authorities and local governments to adjust the main directions of fiscal policy. Changes in the financial stability of a number of budgets of Ukraine during the period under review are characterized by positive dynamics and movement/migration to clusters that combine budgets with a more stable financial position. However, in 2020 there was a move to a cluster that combines budgets with weak financial stability. This indicates the accumulation of problems in the budget system, the difficulty of meeting the targets of local budgets due to negative endogenous and exogenous factors and the need to adjust the fiscal policy of the central government and local governments.

In order to improve the filling of revenue and optimize expenditures of local budgets as well as meet societal needs, local leadership must be flexible and adapt management to changes in the economic, budgetary and social spheres. Monitoring the financial stability of local budgets will facilitate the timely identification and diagnosis of problems and identification of their causes, which is important for making sound management decisions of current and strategic nature. Simplification of the process of assessing the financial sustainability of local budgets using Kohonen's self-organizing maps is an important condition for its active practical application and at the same time will visualize information for the public about the state of local budgets which will promote transparency in budget management, discipline and activity of citizens in the formation of priorities of fiscal policy at the local level.

A further direction of the study is the study of the risks of violation of the financial stability of local budgets and ways to neutralize them.

\section{REFERENCES}

[1] Aleksandrova-Zlatanska C. K, "Evaluating the factors for fiscal stability of rural municipalities: the case of Bulgaria," Problems of Agricultural Economics, vol. 3, no. 360, pp.

\section{6-170, 2019. https://doi.org/10.30858/zer/112131}

[2] Bojarko I.M., Ljuta O.V., Pigul' O.V., "Stijkist' miscevogo bjudzhetu jak element finansovogo mehanizmu upravlinnja social'no-ekonomichnym rozvytkom mista [Stability of the local budget as an element of the financial mechanism of management of social and economic development of the city]. Ekonomichnyj prostir," Economic space, vol. 61, pp. 97-108. (In Ukrainian) 2012.

[3] Bondaruk T., Bondaruk I., Dubyna M., "Methodical tools for assessing the financial stability of local budgets of Ukraine," Svit finansiv, vol. 2, pp. 60-72, 2019.

[4] Cabaleiro R., Buch E., Vaamonde A., "Developing a method to assessing the municipal financial health," The American Review of Public Administration, vol. 46, no. 6, pp. 729-751, 2013. https://doi.org/10.1177/027507401245 1523.

[5] Caldas P., Dollery B., Cunha Marques R. "Can We Put Numbers on Municipal Performance and Sustainability?” A New Strategic Paradigm. Lex Localis, vol. 16, no. 3, pp. 631 - 647, 2018. https://doi.org/10.4335/16.3.631-647.

[6] Cevik S., "V. Nanda. Riding the Storm: Fiscal Sustainability in the Caribbean," IMF Working Paper. Western Hemisphere Department. January 2020. https://www.imf.org/en/Publications/WP/Issues/2020/01/3 1/Riding-the-Storm-Fiscal-Sustainability-in-the-Caribbean -48950.0 .

[7] Chugunov I., Makohon V., "Fiscal strategy as an instrument of economic growth," Baltic Journal of Economic Studies, vol. 5, no. 3, pp. 213-217, 2019. https://doi.org/10.30525/2256-0742/2019-5-3-213-217.

[8] Dalievska T., "Matrix method of cluster assessment of financial sustainability of local government budgets," Economic Bulletin of the University, vol. 32, no. 1, pp. 214-222, 2017.http://nbuv.gov.ua/UJRN/ecvu_2017_32(1) -31 .

[9] Deboeck G.I., "Financial applications of self-organizing maps," Neural Network World, vol. 8, no. 2, pp. 213-241, 1998.

[10] Gede A.Y., Gusti A.P., "Key elements of local government transparency in new public governance," Problems and Perspectives in Management, vol. 18, no. 4, pp. 96-106, 2020. doi:10.21511/ppm.18(4).2020.09.

[11] Guido D., Kohonen, T., Visual Explorations in Finance with self-organizing maps. Springer-Verlag, 1998.

[12] Joseph J., Indratmo I., "Visualizing stock market data with self-organizing map." North America: Florida Artificial Intelligence Research Society Conference, 2013.

[13] Kiang M.Y., "Extending the Kohonen self-organizing map networks for clustering analysis," Computational Statistics \& Data Analysis, vol. 38, pp. 161-180, 2001.

[14] Kohonen T., Self-Organizing Maps (2nd edn). Berlin: Springer, 1997.

[15] Kohonen, T. MATLAB Implementations and Applications of the Self-Organizing Map. Unigrafia Oy, Helsinki, Finland. 2014.

[16] Kostyrko L., Velentejchyk N., "Methodical bases of the 
complex analysis of financial stability of local budgets," Financial Space, vol. 1, pp. 83-90, 2016.

[17] Kumar P. R., Ravi V..., "Bankruptcy prediction in banks and firms via statistical and intelligent techniques," European Journal of Operational Research, vol. 180, pp. 1-28, 2007.

[18] Luchko M. R., "Decentralization: some issues of the methodology of analysis of the effectiveness of local budget management," Galician Economic Bulletin, vol. 2, pp. 121128, 2018.

[19] Lysiak L., Kachula S., Hrabchuk O., Filipova M., Kushnir A., "Assessment of financial sustainability of the local budgets: case of Ukraine," Public and Municipal Finance, vol. 9, no. 1, pp. 48-59, 2020. https://businessperspectives.org/journals/public-and-munic ipal-finance/issue-361/assessment-of-financial-sustainabilit y-of-the-local-budgets-case-of-ukraine.

[20] Mangiameli P., Chen S. K., West D., "A comparison of SOM neural network and hierarchical clustering methods," European Journal of Operational Research, vol. 93, no. 2, pp. 402-417, 1996.

[21] Mel'nychuk N., "Actual problems of budget management in modern conditions," Accounting, Analysis and Audit: Problems of Theory, Methodology, Organization, vol. 2, no. 17, pp. 104-110, 2016.

[22] Ministry of Finance of Ukraine. Statistical publication "Budget of Ukraine 2020". https://www.mof.gov.ua/storage/files/2_Budget_of_Ukrain e_2019_(for_website)\%20(1).pdf, 2021.

[23] Mints O., "Neural network methods for forecasting the reliability of Ukrainian banks," Neuro-Fuzzy Modeling Techniques in Economics, vol. 7, no. 1, pp. 74-85, 2018. doi:10.21511/nfmte.7.2018.05, 2018.

[24] M'jachyn V.Gh., Kucynsjka M.V., "Application of Kohonen maps for the analysis of financial condition and determine the probability of bankruptcy innovation active enterprises,". Scientific Bulletin of Kherson State University. Series: Economic Sciences, vol. 21, no. 2, pp. 71-76, 2016.

[25] Padovani E., Iacuzzi S., Jorge S., Pimentel L., "Municipal financial vulnerability in pandemic crises a framework for analysis," Journal of Public Budgeting, Accounting \& Financial Management, vol.33, no.4, 2021. https://doi.org/10.1108/JPBAFM-07-2020-0129.

[26] Rozskazov A.G., Chaliuk Y.O., Anishchenko V.O., Smal I., Matviichuk O., "Implementing of the COM-B Model in
In-Service Training of Civil Servants as a Prerequisite for Effective Public Governance," Academic Journal of Interdisciplinary Studies, vol.10, no.3, pp. 224-235, 2021. http://www.richtmann.org/journal/index.php/ajis/article/vie w/12466

[27] Santis S., "The Demographic and Economic Determinants of Financial Sustainability: An Analysis of Italian Local Governments," Sustainability, vol. 12, 7599, 2020. https://doi.org/10.3390/su12187599.

[28] Sarlin P., Peltonen T.A., "Mapping the State of Financial Stability," ECB Working Papers Series, No. 1382, 2011. https://www.ecb.europa.eu/pub/pdf/scpwps/ecbwp1382.pd f.

[29] Sebestova J., Majerova I., Szarowska I., "Indicators for assessing the financial condition and municipality management," Administratie si Management Public, vol. 31, pp. 97-110, 2018. DOI: 10.24818/amp/2018.31-07.

[30] Spreen T.L., Afonso W., Gerrish E., "Can Employee Training Influence Local Fiscal Outcomes?" The American Review of Public Administration, vol. 50, no. 4-5, pp.401-414, 2020. doi:10.1177/0275074020911717.

[31] Starostenko N.V., Methodical approaches to the estimation of financial stability of the city budget," Ekonomika Ukrainy, vol. 9, pp. 39-47, 2005.

[32] State Statistics Service of Ukraine. Regional statistics, 2021. http://www.ukrstat.gov.ua/.

[33] The Verkhovna Rada of Ukraine. "Budget Code of Ukraine of June 21, 2001 No. 2542”, Holos Ukrainy, vol. 129, 2001.

[34] Yorek N., Ugulu I., Aydin H., "Using Self-Organizing Neural Network Map Combined with Ward's Clustering Algorithm for Visualization of Students' Cognitive Structural Models about Aliveness Concept," Computational Intelligence and Neuroscience, vol. 7, pp. 1-15, 2016. https://doi.org/10.1155/2016/2476256, 2016.

[35] Zafra-Gómez J.L, López-Hernández A.M., Hernández-Bastida A., "Evaluating Financial Performance in Local Government: Maximizing the Benchmarking Value," International Review of Administrative Sciences, vol. 75, pp. 151-167, 2009. https://doi.org/10.1177/0020852308099510.

[36] Zarucjka O., "General financing of the approach to large-scale distribution of Ukrainian banks on the basis of structural and functional groups," Bulletin of the National Bank of Ukraine, vol. 10, pp. 20-24, 2012. 